\title{
THE ROLE OF MW PLASMA TREATMENT ON THE CORROSION RESISTANCE OF STAINLESS STEELS
}

\author{
ROLA OBRÓBKI PLAZMĄ MV NA ODPORNOŚĆ KOROZYJNĄ STALI STOPOWYCH
}

\begin{abstract}
Two stainless steels (S32404 duplex and S32615 austenitic) were subject to the carbon/nitrogen plasma treatment to examine the role of alloy composition and structure in the behavior of surface during modification. The modification process was performed in the electron cyclotron resonance (ECR) micro wave plasma system, with the frequency of $2.45 \mathrm{GHz}$ and the generator power of $350 \mathrm{~W}$, and with the use of reactive gas mixtures containing $\mathrm{CH}_{4}$ and $\mathrm{N}_{2}$, at the low temperature of $400^{\circ} \mathrm{C}$ and under pressure of $0.2 \mathrm{Tr}$. The treated surface was analyzed by means of X-ray photoelectron spectroscopy (XPS). The corrosion resistance of the samples was determined on the basis of LSV polarization curves in 3\% sodium chloride solution at $37^{\circ} \mathrm{C}$. The treated steel surfaces showed a higher tendency for passivation and higher pitting corrosion resistance compared to the non-modified surfaces.
\end{abstract}

Keywords: MW plasma carbonitriding, stainless steel, corrosion, XPS

Obróbkę powierzchni wysokostopowych stali chromowo-niklowej typu duplex S32404 i austenitycznej S32615 przeprowadzono poprzez węgloazotowanie przy użyciu techniki próżniowej z mikrofalowym wspomaganiem plazmowym o częstotliwości $2.45 \mathrm{GHz}$ i mocy generatora $350 \mathrm{~W}$. Zastosowano reaktywną mieszaninę gazową zawierającą $\mathrm{CH}_{4} \mathrm{i} \mathrm{N}_{2} \mathrm{~W}$ warunkach niskiego ciśnienia $0.2 \mathrm{Tr}$, przy niskiej temperaturze $400^{\circ} \mathrm{C}$. Oceniono wpływ składu chemicznego i struktury stopów na tworzącą się warstwę wierzchnią podczas obróbki. Strukturę powierzchni analizowano za pomocą rentgenowskiej spektroskopii fotoelektronów (XPS). Odporność korozyjną próbek określano na podstawie krzywych polaryzacyjnych LSV w 3\% roztworze chlorku sodu przy temperaturze $37^{\circ} \mathrm{C}$. Powierzchnie stali poddane obróbce wykazały wyższą skłonność do pasywacji w oraz podwyższały odporność na korozję wżerową w porównaniu z powierzchniami niemodyfikowanymi.

\section{Introduction}

The stainless steels are very important technological materials, which exhibit resistance to corrosion in many environments, and find many applications in devices used in various aspects of life (such as biomedicine), as well as various industrial technologies (mining, chemical, petrochemical, pharmaceutical etc.). The certain limitations in their application result from some disadvantageous physical properties, such as a relatively low hardness, a lack of wear resistance and a low resistance to local corrosion, especially pitting corrosion, in environments containing chloride ions at higher temperature. In the last decades, an intense research in the field of surface engineering has been done, which aims at improving the tribological properties of materials. Various types of thermochemical surface treatment (carbonizing, nitriding, carbonitriding), performed using modern techniques (PVD, CVD, with different kinds of plasma or laser support) are the most often applied modification methods [1-6]. The high-temperature techniques of surface treatment $\left(\mathrm{T}>500^{\circ} \mathrm{C}\right)$, leading to the formation of carbides and/or nitrides (mainly of iron and chromium) in the outer layer, increase the surface hardness, however, they usually cause a drop in the corrosion resistance of the steels, as a result of chromium segregation [1-3]. The low-temperature plasma techniques $\left(\mathrm{T}<500^{\circ} \mathrm{C}\right)$, developed in the recent years, enable to introduce nitrogen and/or carbon in the form of solid solution into the matrix without the formation of harmful chromium nitrides or carbides. The resulting super saturation solid solutions $\gamma_{N}$ and/or $\gamma_{C}$, so called expended austenite or $\mathrm{S}$ phase, exhibit higher hardness and better corrosion resistance than $\gamma$ austenite [4-8]. The structure and properties of the modified steel surface depend on the processing parameters (temperature, time, plasma type, pressure), as well as on the properties of the untreated substrates [9-12]. So far, the study has been mainly focused on the selection of the parameters of thermochemical treatments of basic commercial austenitic stainless steels (SS), S30403 (304) and S31603 (316). Recently, a hybrid treatment process integrating the low temperature nitriding and carburizing process has been developed. The process is carried out by introducing nitriding and carburising species to plasma media to effect the simultaneous incorporation of nitrogen and carbon into the surface of austenitic

\footnotetext{
* AGH - UNIVERSITY OF SCIENCE AND TECHNOLOGY, FACULTY OF FOUNDRY, DEPARTMENT OF CHEMISTRY AND CORROSION OF METALS, 23 REYMONTA STR., 30-059 KRAKÓW POLAND

** JAGIELLONIAN UNIVERSITY, FACULTY OF CHEMISTRY, DEPARTMENT OF CHEMICAL TECHNOLOGY, INGARDENA 3, 30-060 KRAKÓW, POLAND
} 
stainless steels with the purpose to form a hybrid structure $[6,13]$. Some works have shown that the carbonitrided surfaces on austenitic stainless steels are characterized by two or three sub-layers: superficial top layer composed of amorphous or nanocrystalline carbonitrides and other two sublayers - composed of nitride and carbide phases mixed with polycrystalline solid solution phases [14-18]. The possibility of achievement of two different metastable solid solutions was reported.

Different mechanisms were proposed for plasma treatment of stainless steel [19-21]. According to Rahman et al.[16,17] the carbonitriding process of stainless steels occurs through the simultaneous reactions between nitrogen and carbon plasma species and the substrate surface (deposition of hydrogenated carbonitride film mixed with carbon powder superfacial top layer) and diffusion of nitrogen and carbon underneath the top layer forming of solid solutions phases. The thickness of the top layer depends on treatment temperature and has approximately $2-3 \mu \mathrm{m}$ at $490^{\circ} \mathrm{C}$ [17]. The superficial amorphous carbide or carbonitride / crystalline layer can play a significant role in protecting materials against corrosion. $\mathrm{Li}$ and Chung [22] reported a good corrosion performance of ultra smooth $\mathrm{CN}_{x}$ overcoats. Only few works [23-25] presented the results of plasma treatment (only nitriding) of duplex and special steels, but the effects of carbonitriding process are unknown. In the presented work the properties of two MW plasma carbonitrided stainless steels with different composition and structure (duplex S32404 and austenitic S32615 containing silicon) were investigated. The research focused on the top layer of the steels and their corrosion performance behavior.

\section{Experimental part}

Duplex S32404 and austenitic stainless steels S32615 were studied. The chemical composition of steels was determined by means of an atomic emission spectrometer (SpektromaxX). Raw surfaces before electrochemical and PACVD treatment was ground and polished with abrasive paper with the gradation from 200 to 1200 . The modification of the steel surface (plasma carbonitriding) was performed in a MW plasma reactor. The treatment process was carried out in a mixture of nitrogen and methane flowing with a total rate of 53 $\mathrm{cm}^{3} /$ min $\left(48 \mathrm{~cm}^{3} / \operatorname{min~} \mathrm{N}_{2}+5 \mathrm{~cm}^{3} /\right.$ min $\left.\mathrm{CH}_{4}\right)$. The working pressure in the chamber equaled $0.2 \mathrm{Tr}$. The carbonitriding process was conducted at $400^{\circ} \mathrm{C}$ for 4 hours. The surface of the samples before the treatment was degreased with acetone and subsequently subjected to reduction in the mixture of argon $\left(50 \mathrm{~cm}^{3} / \mathrm{min}\right)$ and hydrogen $\left(50 \mathrm{~cm}^{3} / \mathrm{min}\right)$ at $400^{\circ} \mathrm{C}$ for $30 \mathrm{~min}$.

The raw and the treated steels were analyzed using X-ray photoelectron spectroscopy (XPS) in the system created by Prevac, equipped with a Scienta R3000 analyzer. The photoelectron spectra were recorded with pass energy of 100 $\mathrm{eV}$ using monochromatized $\mathrm{Al} \mathrm{K} \alpha$ radiation. The power of the applied radiation measured in front of the monochroma- tor was $350 \mathrm{~W}$, whereas the estimated power reaching the sample was $175 \mathrm{~W}$. The working pressure during the measurements was $<7 \cdot 10^{-9}$ mbar. The tests on the samples were conducted with three-fold etching of the surface with Ar ions, with the following parameters: energy $-2 \mathrm{keV}$, ion current - $3.35 \mu \mathrm{Acm}^{-1}$, etching time $7 \mathrm{~min}$. The collected spectra were smoothed and the Shirley background was subtracted by means of CasaXPS software (version 2.3.15). The binding energy was calibrated according to the $\mathrm{Au} 4 \mathrm{f} 7 / 2$ maximum $(84.0 \mathrm{eV})$. Gaussian-Lorentzian shape GL(30) curve was used for peak fitting. In the quantitative analysis, the relative sensitivity coefficients available in the CasaXPS database were applied.

Corrosion resistance was determined on the basis of polarization measurements in aqueous solution of sodium chloride $(3 \% \mathrm{NaCl})$ at $37^{\circ} \mathrm{C}$ (in respect of biomedical application). The samples were immersed in epoxide resin, and the active surface was washed with acetone. The polarization was performed with the potentiokinetic technique (LSV) using the potential sweep rate, $\mathrm{dE} / \mathrm{dt}$, equaling 1,3 and $5 \mathrm{~V} / \mathrm{min}$., in a classical tri-electrode system. The counter electrode was a platinum electrode, and as a reference electrode, $\mathrm{Ag} / \mathrm{AgCl}$ one was applied. The potentiometric measurements of the corrosive potential, Ec(t), were conducted in time needed to determine its value (about $0.5 \mathrm{~h}$ ).

\section{Results and discussion}

\subsection{XPS study}

Two types of steel investigated in this study differ in microstructure and chemical composition. Steel S32404 has an austenitic-ferritic structure (duplex), and steel S32615 - a monophase austenitic one. The chemical compositions of the tested steels determined on the basis of the spectral emission analysis are presented in Tabele 1.

Tabele 2 demonstrates the element content on the raw and the treated surfaces, calculated on the basis of the amount of counts measured during the XPS experiments. It can be noticed that the surface composition differs significantly compared to the bulk. The outer layer of the studied samples is clearly enriched in carbon and oxygen atoms, which dominate both on the raw and the modified surfaces. The presence of these elements, can be related to the contact of the studied samples with air atmosphere, before the XPS analysis. Similar result of the XPS analysis was obtained in other works [26-28].

It should be emphasized that all samples before carbonitriding were etched in an MV plasma reactor, in hydrogen and argon atmosphere, in order to remove the natural film.

On the outer layer of the modified steels, beside carbon, oxygen and nitrogen, we observed the presence of iron, chromium and silicon. The signal originated from nickel was not detected like in other works presented in literature $[19,27]$. 
TABLE 1

Chemical composition of steels

\begin{tabular}{|c|c|c|c|c|c|c|c|c|}
\hline \hline \multirow{2}{*}{ Grade of steel } & \multicolumn{9}{|c|}{ Content [\% mass.]/[\% at.] } \\
\cline { 2 - 9 } & $\mathrm{C}$ & $\mathrm{Si}$ & $\mathrm{Mn}$ & $\mathrm{P}$ & $\mathrm{Cr}$ & $\mathrm{Ni}$ & $\mathrm{Mo}$ & $\mathrm{Cu}$ \\
\hline \multirow{2}{*}{ Duplex S32404 } & $0.03 /$ & $0.59 /$ & $1.60 /$ & $0.02 /$ & $20.40 /$ & $7.50 /$ & $2.33 /$ & $1.52 /$ \\
& 0.14 & 1.21 & 1.66 & 0.04 & 22.45 & 7.27 & 1.39 & 1.38 \\
\hline \multirow{2}{*}{ Austenitic S32615 } & $0.07 /$ & $5.50 /$ & $1.90 /$ & - & $18.50 /$ & $21.00 /$ & $1.20 /$ & - \\
& 0.31 & 10.41 & 1.83 & - & 18.85 & 18.87 & 0.66 & - \\
\hline
\end{tabular}

TABLE 2

Element content in outer layer of steel determined by XPS analysis

\begin{tabular}{|c|c|c|c|c|c|c|c|c|c|c|}
\hline \hline \multirow{2}{*}{ Steel grade } & \multicolumn{10}{|c|}{ Content [\% at.] } \\
\cline { 3 - 12 } \multicolumn{2}{|c|}{} & $\mathrm{Fe}$ & $\mathrm{Cr}$ & $\mathrm{Ni}$ & $\mathrm{Mn}$ & $\mathrm{Si}$ & $\mathrm{Mo}$ & $\mathrm{C}$ & $\mathrm{N}$ & $\mathrm{O}$ \\
\hline \multirow{2}{*}{$\mathrm{S} 32404$} & Raw & 7.54 & 4.59 & 0.58 & 1.85 & 0 & 0 & 39.34 & 0 & 46.10 \\
\cline { 2 - 12 } & $\mathrm{CN}$ & 17.25 & 1.41 & 0 & 0 & 4.97 & 0 & 29.72 & 8.66 & 37.99 \\
\hline \multirow{2}{*}{$\mathrm{S} 32615$} & Raw & 5.68 & 5.69 & 1.00 & 1.42 & 3.47 & 0 & 42.72 & 0 & 40.03 \\
\cline { 2 - 11 } & $\mathrm{CN}$ & 10.18 & 2.36 & 0 & 0.36 & 3.56 & 0 & 32.80 & 9.33 & 41.41 \\
\hline
\end{tabular}

Fig. 1 presents cross section of modified surfaces of both steels measured by XPS using $\mathrm{Ar}^{+}$ion sputtering up to 21 min. The component distribution profile indicates diffusion of carbon and nitrogen underneath the top surface layer and segregation of alloying components.

The depth profile of carbon and nitrogen (Fig. 1) is consistent with other results [16-18] and suggests that the carbonitided surfaces of both steels consist of three sub-layers: a top coating layer where carbon and nitrogen remains almost on the same level, and two diffusion sub layer marked by a change in the concentration of structural components. Moreover, the cross sections indicate that alloying elements of steel segregate in the carbonitriding process to the grade extend. The segregation phenomena (especially observed in the case of silicon) was found during the thermal treatment of iron silicon system [31-33].
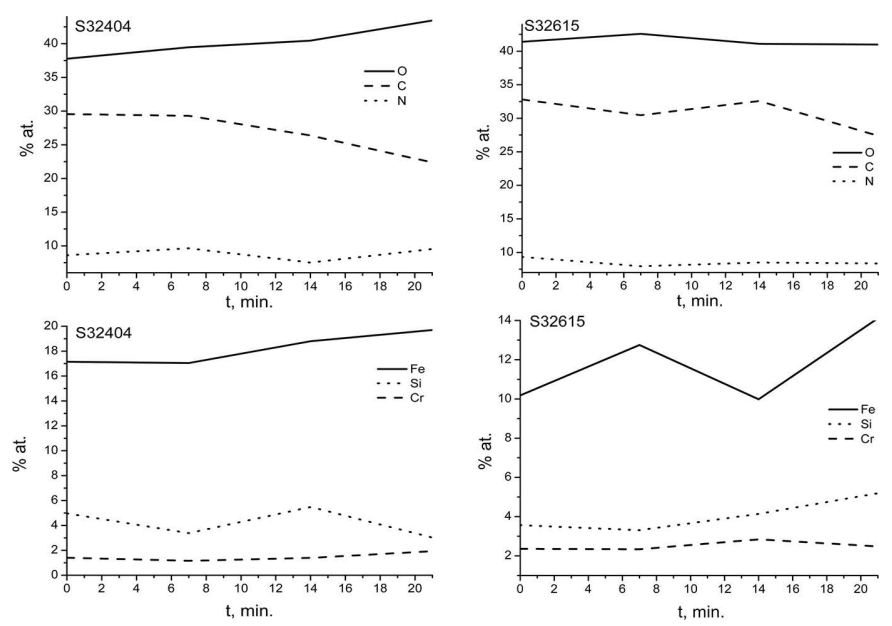

Fig. 1. Depth profiles composition for treated stainless steels obtained from XPS analysis, using $\mathrm{Ar}^{+}$ion sputtering
The characteristic core-level signals in the recorded XPS spectra reveal a complex surface structure, not only in respect of the content of the individual elements, but also of the formation of various compounds. The deconvoluted spectra of Fe $2 \mathrm{p}, \mathrm{Cr} 2 \mathrm{p}, \mathrm{Si} 2 \mathrm{p}, \mathrm{C} 1 \mathrm{~s}, \mathrm{~N} 1 \mathrm{~s}$ and $\mathrm{O} 1 \mathrm{~s}$ for the carbonitrided S23404 and S32615 steels are illustrated in Fig. 2 and 3, respectively. The values of the binding energy of photoelectrons $\left(\mathrm{E}_{B}\right)$ in the particular bands and their corresponding bonds (compounds) are presented in Tabele 3 a (for Fe 2p3/2), b (for $\mathrm{Cr} 2 \mathrm{p} 3 / 2)$, c (Si 2p), d (C 2p), e (N 1s), and f (O 1s).

The binding energy values of the emitted photoelectrons in the $\mathrm{Fe} 2 \mathrm{p} 3 / 2$ band, originating from the modified surfaces of both types of steel, show the presence of iron oxides $\mathrm{Fe}_{3} \mathrm{O}_{4}$ and $\mathrm{Fe}_{2} \mathrm{O}_{3}$ with a small content of metallic iron. The presence of the signal from the metallic iron is the evidence for a very little thickness of the surface layer, not exceeding the depth of the XPS analysis (about $5 \mathrm{~nm}$ ). Stronger $\mathrm{Fe}^{0}$ signal for the modified austenitic steel indicates a thinner top coating layer compared to the layer on duplex steel.

In the $\mathrm{Cr} 2 \mathrm{p} 3 / 2$ spectra several constituents, shown in Table 5b, can be distinguished. Chromium is present mainly in the form chromium oxides $\mathrm{Cr}_{2} \mathrm{O}_{3} / \mathrm{CrOOH}$ on both modified surfaces. The signal from metallic chromium, similarly to iron, is stronger on the treated surface of austenitic steel.

Silicon is one of the main alloy components present on the treated surfaces. The $\mathrm{E}_{B}$ values for the $\mathrm{Si} 2 \mathrm{p}$ spectra (Tabele $3 \mathrm{c}$ ) point to the presence of different silicon compounds. These values are most similar to the $\mathrm{E}_{B}$ related to the silicon atoms bounded with nitrogen, carbon and oxygen, in silicon-organic like compounds. The presence of more complicated compounds is suggested by the lack of peaks at lower energy values in bands $\mathrm{C} 1 \mathrm{~s}$ and $\mathrm{N} 1 \mathrm{~s}$, ascribed to simple carbides and nitrides. The possibility of the presence of silicon-organic like compounds is also verified by the $\mathrm{E}_{B}$ values for the bands of carbon and nitrogen (Tabele $3 \mathrm{~d}$ and $3 \mathrm{e}$ ), as well as of oxygen (Tabele $3 \mathrm{f}$ ). 

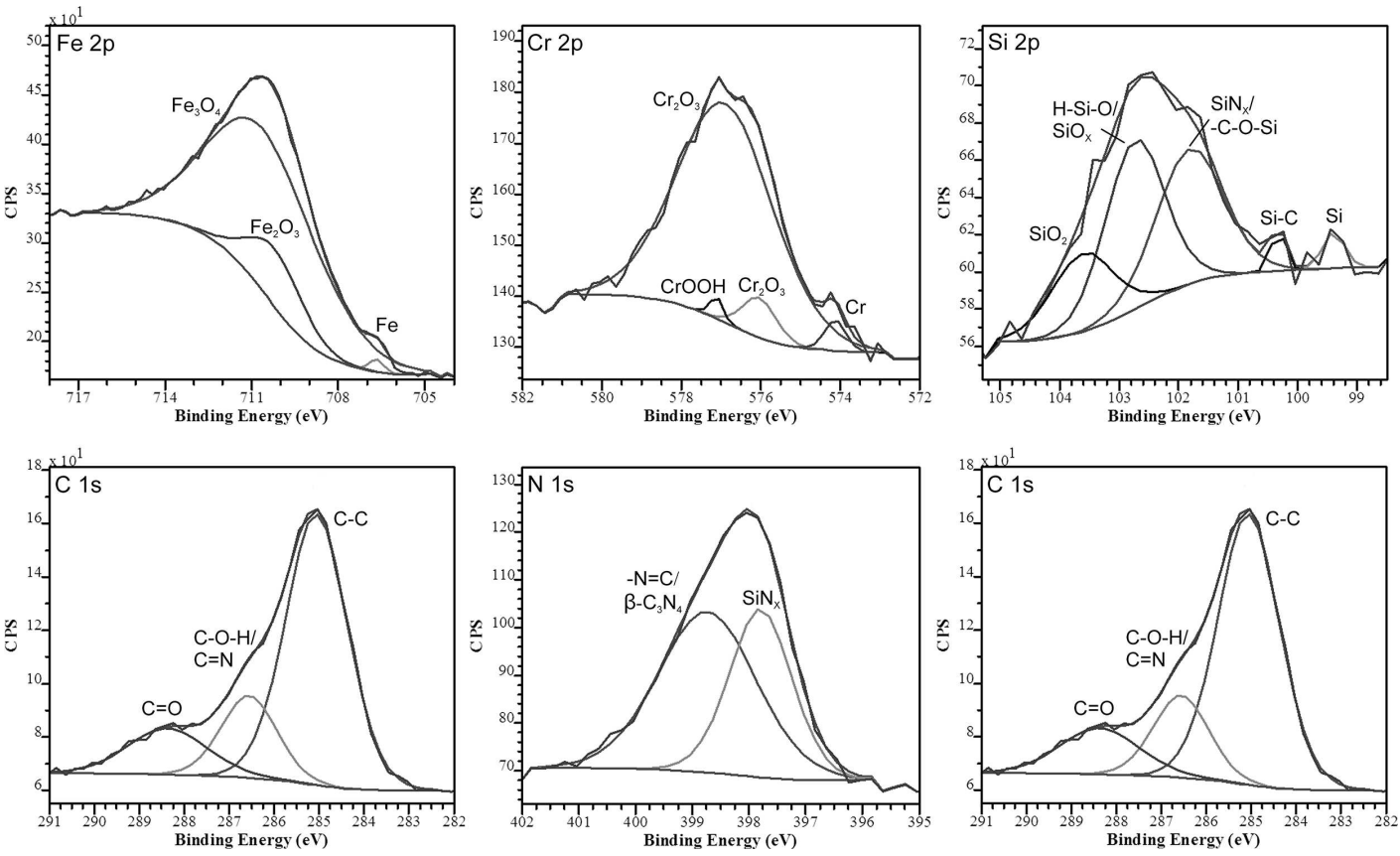

Fig. 2. XPS spectra of duplex stainless steel S23404 after plasma modification
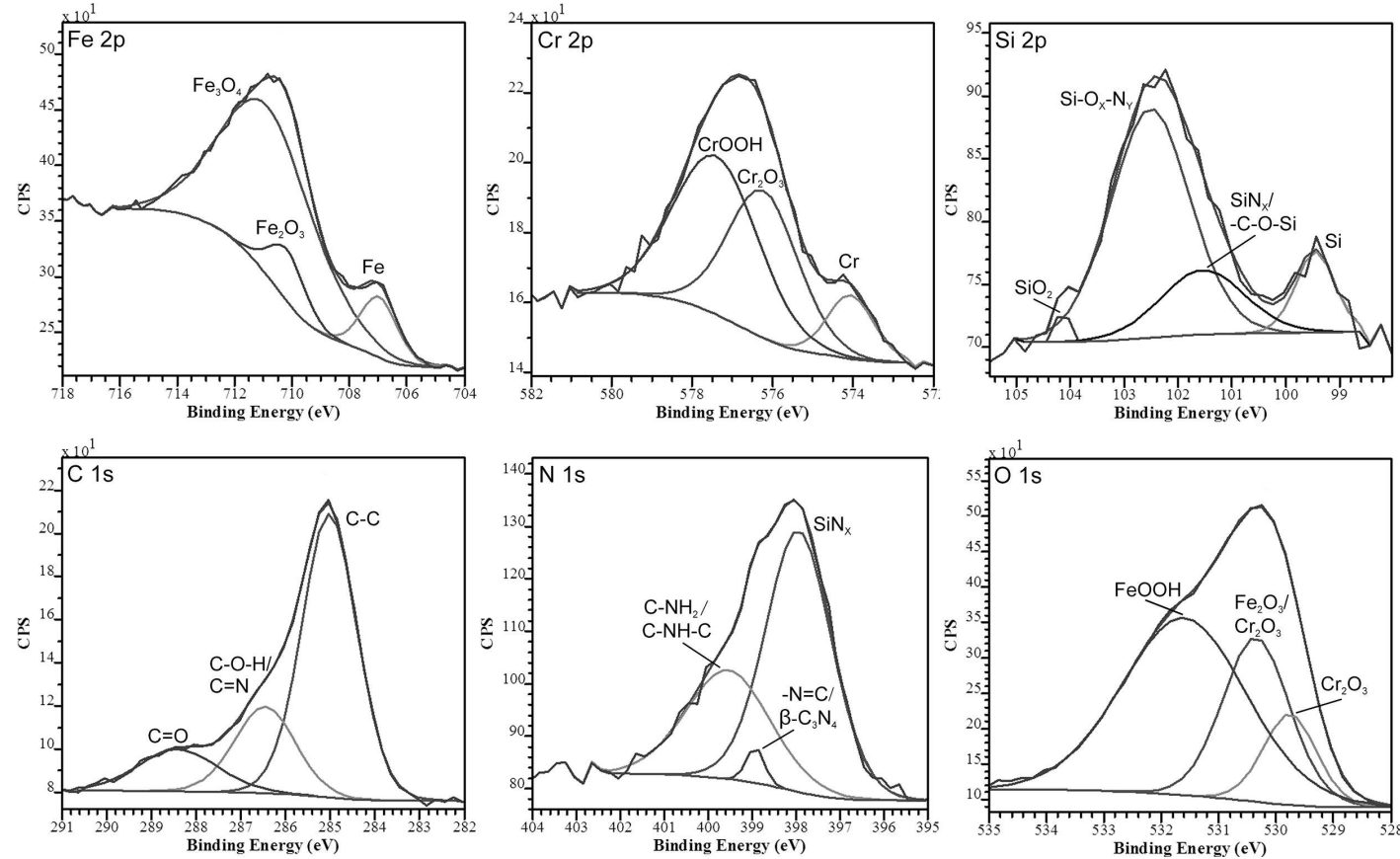

Fig. 3. XPS spectra of austenitic S22615 stainless steel after plasma modification

TABLE 3a

Energy values $\mathrm{E}_{B}$ for band $\mathrm{Fe} 2 \mathrm{p} 3 / 2$ of carbonitrided surfaces

\begin{tabular}{|c|c|c|c|c|c|}
\hline \multirow{2}{*}{$\begin{array}{l}\text { Grade } \\
\text { Band }\end{array}$} & \multicolumn{2}{|c|}{ S32404 } & \multicolumn{2}{|c|}{ S32615 } & \multirow{2}{*}{$\begin{array}{l}\text { Compound/ } \\
\mathrm{E}_{B}[\mathrm{eV}] / \text { Ref. }\end{array}$} \\
\hline & $\mathrm{E}_{B}[\mathrm{eV}]$ & $\begin{array}{c}\text { Cont. } \\
{[\%]}\end{array}$ & $\mathrm{E}_{B}[\mathrm{eV}]$ & $\begin{array}{c}\text { Cont. } \\
{[\%]}\end{array}$ & \\
\hline \multirow{3}{*}{$\mathrm{Fe} 2 \mathrm{p} 3 / 2$} & 706.7 & 1.0 & 707.0 & 11.6 & $\begin{array}{l}\text { Fe in alloy / } \\
707.2 /[34]\end{array}$ \\
\hline & 710.2 & 15.1 & 710.2 & 10.1 & $\begin{array}{c}\mathrm{Fe}_{2} \mathrm{O}_{3} / \\
710.4 /[35]\end{array}$ \\
\hline & 710.6 & 83.9 & 710.8 & 78.3 & $\begin{array}{c}\mathrm{Fe}_{3} \mathrm{O}_{4} / \\
710.7 /[34]\end{array}$ \\
\hline
\end{tabular}

TABLE $3 b$ Energy values $\mathrm{E}_{B}$ for band $\mathrm{Cr} 2 \mathrm{p} 3 / 2$ of carbonitrided surfaces

\begin{tabular}{|l|c|c|c|c|c|}
\hline \multirow{2}{*}{ Grade } & \multicolumn{2}{|c|}{$\mathrm{S} 32404$} & \multicolumn{2}{|c|}{$\mathrm{S} 32615$} & \multirow{2}{*}{$\begin{array}{c}\text { Compound/ } \\
\mathrm{E}_{B} \text { [eV]/Ref. }\end{array}$} \\
\cline { 2 - 5 } & $\mathrm{E}_{B}[\mathrm{eV}]$ & $\begin{array}{c}\text { Cont. } \\
{[\%]}\end{array}$ & $\mathrm{E}_{B}[\mathrm{eV}]$ & $\begin{array}{c}\text { Cont. } \\
{[\%]}\end{array}$ & \\
\hline \multirow{3}{*}{$\mathrm{Cr} 2 \mathrm{p} 3 / 2$} & 574.1 & 2.8 & 574 & 10.4 & $\mathrm{Cr} / 574.0 /[34]$ \\
\cline { 2 - 5 } & 576.1 & 5.8 & 576.3 & 41.4 & $\mathrm{Cr}_{2} \mathrm{O}_{3} / 576.5 /[34]$ \\
\cline { 2 - 5 } & 576.9 & 90.1 & 0 & 0 & $\begin{array}{c}\text { hydrated } \\
\mathrm{Cr}_{2} \mathrm{O}_{3} / 576.9 /[35]\end{array}$ \\
\cline { 2 - 5 } & 577.1 & 1.3 & 577.4 & 48.2 & $\mathrm{CrOOH}_{2577.1 /[36]}$ \\
\hline
\end{tabular}


TABLE 3c

Energy values $\mathrm{E}_{B}$ of band $\mathrm{Si} 2 \mathrm{p}$ for the carbonitrided surfaces

\begin{tabular}{|c|c|c|c|c|c|}
\hline \multirow{2}{*}{$\begin{array}{l}\text { Grade } \\
\text { Band }\end{array}$} & \multicolumn{2}{|c|}{ S32404 } & \multicolumn{2}{|c|}{ S32615 } & \multirow{2}{*}{$\begin{array}{l}\text { Compound/ } \\
\mathrm{E}_{B}[\mathrm{eV}] / \text { Ref. }\end{array}$} \\
\hline & $\begin{array}{c}\mathrm{E}_{B} \\
{[\mathrm{eV}]}\end{array}$ & $\begin{array}{l}\text { Cont. } \\
{[\%]}\end{array}$ & $\begin{array}{c}\mathrm{E}_{B} \\
{[\mathrm{eV}]}\end{array}$ & $\begin{array}{l}\text { Cont. } \\
{[\%]}\end{array}$ & \\
\hline \multirow{6}{*}{ Si $2 p$} & 99.4 & 3.0 & 99.5 & 11.5 & $\mathrm{Si} / 99.2$ / [37] \\
\hline & 100.3 & 2.3 & 0 & 0 & Si-C / 100.5 / [37] \\
\hline & 101.8 & 35.8 & 101.5 & 19.7 & \begin{tabular}{|c|}
$\mathrm{SiN}_{x} / 102.0 /[38]$. \\
$-\mathrm{C}-\mathrm{O}-\mathrm{Si} / 102.1$ / [39]
\end{tabular} \\
\hline & 0 & 0 & 102.5 & 66.4 & $\mathrm{Si}-\mathrm{O}_{x}-\mathrm{N}_{y} / 102.3 /[40]$ \\
\hline & 102.7 & 39.6 & 0 & 0 & $\begin{array}{c}\mathrm{H}-\mathrm{Si}-\mathrm{O} / 102.9 \text { / [39] } \\
\mathrm{SiO}_{x} / 103.2 \text { / [37] } \\
\text { Metylosilikon / } \\
102.9 \text { / [41] }\end{array}$ \\
\hline & 103.6 & 19.25 & 104.1 & 2.4 & $\mathrm{SiO}_{2} / 103.8 /[42]$ \\
\hline
\end{tabular}

The $\mathrm{C} 2 \mathrm{p}$ spectra can be deconvoluted into at least 3 peaks with the binding energy values of $285.0 \pm 0.1 \mathrm{eV}, 286.3 \pm 0.2$ $\mathrm{eV}$ and $288.5 \pm 0.2 \mathrm{eV}$. The lowest value of $\mathrm{E}_{b}$ corresponds to bonds $\mathrm{C}-\mathrm{C}$ and/or $\mathrm{C}-\mathrm{H}$, the medium value is assigned to the carbon-nitrogen bonds in the graphite-like structures with the hybridization of $\mathrm{sp}^{2}$, whereas the highest one is ascribed to the surface carbonyl [38]. The presence of complex structures of carbon and nitrogen is verified by the spectra in the nitride band. The peaks at the energy levels in the range of 398-399 eV, 400-401 eV (Fig. 2, 3 and Tabele 3e) come from the nitrogen coordinated by two or three neighbouring carbon atoms in the graphite-like and $\beta-\mathrm{C}_{3} \mathrm{~N}_{4}$ nitride-like structures [43].

TABLE 3d

Energy values $\mathrm{E}_{B}$ for band $\mathrm{C} 2 \mathrm{p}$ of carbonitrided surfaces

\begin{tabular}{|c|c|c|c|c|c|}
\hline \hline \multirow{3}{*}{ Grade } & \multicolumn{2}{|c|}{$\mathrm{S} 32404$} & \multicolumn{2}{c|}{$\mathrm{S} 32615$} & \multirow{2}{*}{$\begin{array}{c}\text { Compound/ } \\
\mathrm{E}_{B} \text { [eV]/Ref. }\end{array}$} \\
\cline { 2 - 5 } & $\begin{array}{c}\mathrm{E}_{B} \\
{[\mathrm{eV}]}\end{array}$ & $\begin{array}{c}\text { Cont. } \\
{[\%]}\end{array}$ & $\begin{array}{c}\mathrm{E}_{B} \\
{[\mathrm{eV}]}\end{array}$ & $\begin{array}{c}\text { Cont. } \\
{[\%]}\end{array}$ & \\
\hline \multirow{3}{*}{ C 2p } & 285.0 & 66.5 & 285.0 & 64.4 & $\begin{array}{c}\mathrm{C}-\mathrm{C} / 284.7 /[44] \\
\mathrm{C}-\mathrm{H} / 285.0 /[45]\end{array}$ \\
\cline { 2 - 6 } & 286.5 & 17.0 & 286.5 & 21.3 & $\begin{array}{c}\mathrm{C}-\mathrm{O}-\mathrm{H} / 286.4 /[37] \\
\text { Graphite like } \\
\mathrm{C}=\mathrm{N} / 286.1 /[43]\end{array}$ \\
\cline { 2 - 6 } & 288.3 & 16.5 & 288.4 & 14.3 & $\mathrm{C}=\mathrm{O} / 288.4 /[37]$ \\
\hline
\end{tabular}

TABLE $3 e$

Energy values $\mathrm{E}_{B}$ for band $\mathrm{N}$ 1s of carbonitrided surfaces

\begin{tabular}{|c|c|c|c|c|c|}
\hline \multirow{2}{*}{$\begin{array}{l}\text { Grade } \\
\text { Band }\end{array}$} & \multicolumn{2}{|c|}{ S32404 } & \multicolumn{2}{|c|}{ S32615 } & \multirow{2}{*}{$\begin{array}{l}\text { Compound/ } \\
\mathrm{E}_{B}[\mathrm{eV}] / \text { Ref. }\end{array}$} \\
\hline & $\begin{array}{c}\mathrm{E}_{B} \\
{[\mathrm{eV}]}\end{array}$ & $\begin{array}{c}\text { Cont. } \\
{[\%]}\end{array}$ & $\begin{array}{c}\mathrm{E}_{B} \\
{[\mathrm{eV}]}\end{array}$ & $\begin{array}{c}\text { Cont. } \\
{[\%]}\end{array}$ & \\
\hline \multirow{3}{*}{$\mathrm{N} 1 \mathrm{~s}$} & 397.8 & 65.2 & 397.9 & 64.1 & $\mathrm{SiN}_{x} / 397.4$ / [38] \\
\hline & 398.7 & 34.8 & 398.9 & 2.4 & $\begin{array}{c}-\mathrm{N}=\mathrm{C} / 398.7 /[44] \\
\beta-\mathrm{C}_{3} \mathrm{~N}_{4} / 398.5 /[43]\end{array}$ \\
\hline & 0 & 0 & 399.5 & 33.5 & $\begin{array}{c}\mathrm{C}-\mathrm{NH}_{2} \\
\text { C-NH-C / 399.3 / [46] }\end{array}$ \\
\hline
\end{tabular}

The XPS analysis of the carbonitrided steels indicates that during low temperature, low pressure MW plasma carbonitriding, a thin film (top layer) containing a mixture of compounds involving mainly carbon, nitrogen, oxide, with small amount of silicon, iron and chromium is formed on the surfaces of stain- less steels. The superficial top layer consists of graphite-like, nitride-like and/or silicon-organic like compounds as well as a small amount of metal oxides (iron and chromium). As observed the thickness of the top layer has a maximum $5 \mathrm{~nm}$. During carbonitriding, simultaneously with the deposition of carbon and nitrogen and diffusion of $\mathrm{C}, \mathrm{N}$ underneath the top layer the segregation of the alloying elements of steels occurs, what is indicated by the contents of elements in the top layer and the depth profiles of components. Greater degree of segregation and higher enrichment with silicon is observed for the modified surface of duplex stainless steel.

TABLE $3 f$

Energy values $\mathrm{E}_{B}$ for band $\mathrm{O} 1 \mathrm{~s}$ of carbonitrided surfaces

\begin{tabular}{|c|c|c|c|c|c|}
\hline \hline \multirow{3}{*}{ Grade } & \multicolumn{2}{|c|}{$\mathrm{S} 32404$} & \multicolumn{2}{|c|}{$\mathrm{S} 32615$} & \multirow{2}{*}{$\begin{array}{c}\text { Compound/ } \\
\mathrm{E}_{B}[\mathrm{eV}] / \text { Ref. }\end{array}$} \\
\cline { 2 - 5 } & $\begin{array}{c}\mathrm{E}_{B} \\
{[\mathrm{eV}]}\end{array}$ & $\begin{array}{c}\text { Cont. } \\
{[\%]}\end{array}$ & $\begin{array}{c}\mathrm{E}_{B} \\
{[\mathrm{eV}]}\end{array}$ & $\begin{array}{c}\text { Cont. } \\
{[\%]}\end{array}$ & \\
\hline \multirow{4}{*}{ O 1s } & 0 & 0 & 529.8 & 12.8 & $\mathrm{Cr}_{2} \mathrm{O}_{3} / 530 /[35]$ \\
\cline { 2 - 6 } & 530.1 & 54.1 & 530.3 & 28.9 & $\begin{array}{l}\mathrm{Fe}_{2} \mathrm{O}_{3} / 530.2 /[35] \\
\mathrm{Cr}_{2} \mathrm{O}_{3} / 530.3 /[34]\end{array}$ \\
\cline { 2 - 6 } & 530.7 & 12.5 & 0 & 0 & $\mathrm{SiO}_{x} / 530.7 /[47]$ \\
\cline { 2 - 6 } & 0 & 0 & 531.6 & 58.3 & $\mathrm{FeOOH} / 531.4 /[34]$ \\
\cline { 2 - 6 } & 531.9 & 33.4 & 0 & 0 & $\mathrm{C}=\mathrm{O} / 532.2 /[48]$ \\
\hline
\end{tabular}

\subsection{Polarization tests}

Fig. 4 presents the polarization curves LSV of the raw steel surfaces in $3 \% \mathrm{NaCl}$ solution at $37^{\circ} \mathrm{C}$. The tested types of steel belong to the corrosion resistant materials. They undergo spontaneous passivation in chloride environments under stationary conditions. This is verified by the course of the curves at low polarization rates and the value of the corrosion potential (Tabele 4).

However, these steels show the tendency to pitting corrosion in $3 \%$ sodium chloride solutionat a higher temperature $\left(37^{\circ} \mathrm{C}\right)$. This effect is verified by the low values of the breakdown potential, $\mathrm{E}_{P}$, a distinct hysteresis loop on the return of polarization curves and the low value of the repassivation potential, $\mathrm{E}_{R}$. In addition, corrosion potential $\left(\mathrm{E}_{k}\right)$ of investigation steels is situated near the repassivation potential. Steel S32404 is more sensitive to pitting corrosion. The Mo and Si additions, hindering the formation of pits and facilitating the repassivation process $[49,50]$. However at a higher temperature $\left(37^{\circ} \mathrm{C}\right)$ the alloying elements do not provide resistance to the pitting corrosion. The impact mechanism of molybdenum on the corrosion properties of steel, contrary to silicon, has been widely discussed in literature $[49,50]$. The positive influence of silicon is usually associated with the structure of the passive layer enriched with silicon $\left(\mathrm{SiO}_{2}\right)$, especially in oxidizing environments [51, 52]. 

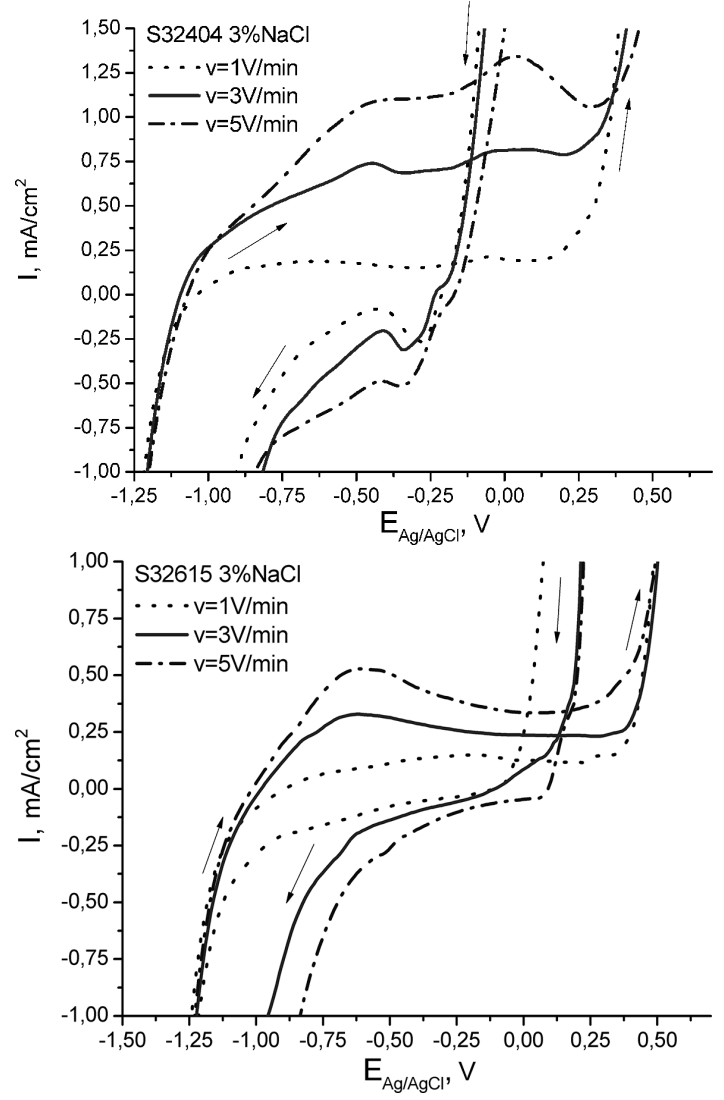

Fig. 4. Polarization curves LSV of the raw S32404 (a) and S32615 (b) surfaces measured at different polarization rates
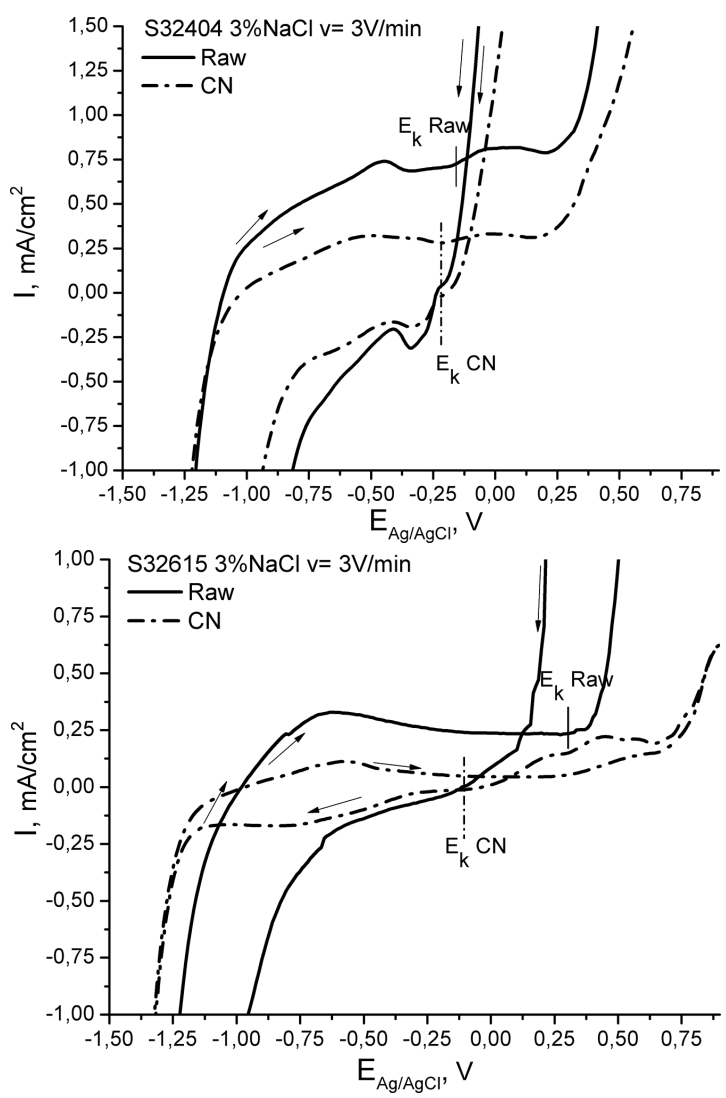

Fig. 5. Polarization curves LSV of the raw and carbonitrided S32404 (a) and S32615 (b) surfaces
TABLE 4

Passivation parameters of tested surfaces in $3 \% \mathrm{NaCl}$

\begin{tabular}{|c|c|c|c|c|c|}
\hline \hline Grade of steel & Surface & $\mathrm{I}_{P}\left[\mathrm{~mA} / \mathrm{cm}^{2}\right]$ & $\mathrm{E}_{K}[\mathrm{~V}]$ & $\mathrm{E}_{P R}[\mathrm{~V}]$ & $\mathrm{E}_{R P}[\mathrm{~V}]$ \\
\hline \multirow{2}{*}{ S32404 } & Raw & 0.74 & -0.15 & 0.30 & -0.12 \\
\cline { 2 - 6 } & $\mathrm{CN}$ & 0.33 & -0.21 & 0.31 & -0.10 \\
\hline \multirow{2}{*}{ S32615 } & Raw & 0.33 & 0.31 & 0.32 & 0.23 \\
\cline { 2 - 6 } & $\mathrm{CN}$ & 0.05 & -0.10 & 0.77 & 0.07 \\
\hline
\end{tabular}

The low-temperature plasma carbonitriding of both steels reduces their anodic current density in the whole range of anodic potentials, and facilitates the transition into the passive state (Fig. 5, Tabele 4). Similar results confirming the positive influence of carbonitriding treatment on the anodic current density of steel (S316), in $3 \% \mathrm{NaCl}$ was obtained by Sun [6]. The values of the breakdown and repassivation potentials (Fig. 5, Tabele 4) indicate that the applied treatment in certain extend improves pitting corrosion resistance. A significant improvement is observed in the case of austenitic steel (with silicon) S32615. This is verified by the passivation parameters: a wide passive area - from about $-0.3 \mathrm{~V}$ to about $+0.77 \mathrm{~V}$ (Fig. 5b), the lack of breakdown potential below $0.7 \mathrm{~V}$ and the higher repassivation potential. These parameters prove the high stability of the passive state and the local corrosion resistance. This resistance is related to formation of the superficial amorphous and/or nanocrystalline carbo-nitride layer. This might be associated with composition and structure of the much thinner top layer. The superficial top layer on the both steels contains graphite-like, nitride-like and/or silicon-organic like compounds as well as a small amount of metal oxides (iron and chromium). However the thickness of the film on the duplex steel is higher. Two-phase structure facilitates the diffusion process which leads to the formation of thicker layer with weaker protective properties.

\section{Conclusions}

From the performed investigations, we can conclude that low-temperature, low pressure MW plasma carbonitriding can increase the resistance to corrosion - also the pitting corrosion - of stainless steels, in the presence of chloride ions, at an elevated temperature $\left(37^{\circ} \mathrm{C}\right)$. The resistance is related to the chemical composition and structure of the top surface layer which is formed during the process. The degree of the surface modification and the corrosion resistance of the steel are significantly affected by the alloy additives (especially silicon) present in the steels. The high corrosion resistance of the treated S32615 steel is related to the formation of thinner top layer containing amorphous and complex compounds of silicon, oxide, carbon and nitrogen, most likely graphite-like, nitride-like and/or silicon-organic like compounds, which is pointed by the XPS analysis.

\section{Acknowledgements}

The research was done with the application of the equipment purchased from the means of European Regional Development Fund, 
within the framework of the Innovative Economy Operational Program (project POIG.02.01.00-12-023/08)

The research was realized with support of the Ministry of Science and Higher Education Republic of Poland (project no. 15.11.170. 453)

\section{REFERENCES}

[1] T. We ber, L. de Wit, F.W. S a r is, A. Konger, B. R a u s ch e n b a ch, G.K. Wolf, S. Kra us s, Mater. Sci. \& Eng. A199, 205 (1995).

[2] E.J. F li s, J. M a ń kow s ki, T. Z a k roc z y m ski, Corros. Sci. 42, 313 (2000).

[3] J. Karwan-Baczewska, T. Dymkowski, J.R. S o bi e cki, T. For m an ski, Archiv. Of Metallurg \& Matter. 55, 385 (2010).

[4] C.K. L e e, H.C. S h i h, J. of the Mater. Sci. 35, 2361 (2000).

[5] T. B e 11, Y. S u n, Heat Treat. of Metals 29, 57 (2002).

[6] Y. S u n, Mater. Lett. 59, 3410 (2005).

[7] C.X. Li, T. B e 11, Corros. Sci. 46, 1527 (2004).

[8] H. D o n g, Y. S u n, T. B e 11, Surf. Coat. Technol. 90, 91 (1997).

[9] M. U d y a v a r, D.J. Yo u n g, Corros. Sci. 42, 861 (2000).

[10] M. A b d E 1-R ah m a n, F.M. E $1-\mathrm{H}$ o s s a r y, T. Fi t z, N.Z. N e g m, F. Prokert, M.T. Pha m, E. Richter, W. M ö 11 e r, Surf. Coat. Technol. 183, 268 (2004).

[11] A.M. E $1-\mathrm{R}$ a h m a n, F.M. E $1-\mathrm{H}$ o s s a r y, F. Proke r t, N.Z. N e g m, N. S chell, E. Richter, W. Möller, Surf. Coat. Technol. 200, 602 (2005).

[12] F.M. E 1 - H o s s a ry, N.Z. Ne g m, S.M. K h a li 1, A.M. A b e d E $1 \mathrm{r}$ a h m a n, D.N. M c Il r o y, Surf. Coat. Technol. 141, 194 (2001).

[13] M. Tsujikawa, N. Yam a u chi, N. Ueda, T. Sone, Y. H i r o s e, Surf. Coat. Technol. 193, 309 (2005).

[14] M. S a m a n d i, Surf. Eng. 11, 156 (1995).

[15] X. Li, M. S a mandi, D. Dunne, R. Hutchinys, Surf. Coat. Technol. 71, 175 (1995).

[16] F.M. E 1 - H o s s a r y, N.Z. N e g m, A.M. A b d E 1 - R a h m a n, M. H a m m a d, Mater. Sci. Eng. C 29, 1167 (2009).

[17] A.M. A b d E 1 - R a h m a n, Surf. \& Coat. Technol. 205, 674 (2010).

[18] T. Czerwie c, H. He, S. We be r, D. C., M. H., Surf. Coat Technol. 200, 5289 (2006).

[19] S. Par a s c a ndola, R. Gün ze l, R. Grötz s che l, E. R i ch ter, W. M ö 11 e r, Nuclear Instruments and Methods in Physics Research B 1281, 136 (1998).

[20] A. B r o k m a n, F.R. Tu l e r, J. Appl. Phys. 21, 468 (1981).

[21] F.M. H o s s a r y, Surf. Coat Technol. 150, 277 (2002).

[22] D.J. L i, Y.W. C h u n g, IEEE Trans. Magn. V 39 (2), 765 (2003).

[23] C. B lawert, A. We isheit, B.L. Mordike, M. K n o o p, Surf. Coat. Technol. 85, 15 (1996).

[24] A. Kli a u ga, M. Poh l, Surf. Coat. Technol. 98, 1205 (1998).
[25] B. Stypuła, A. Stepuch-Galik, K. Kowalski, M. J a n u ś, A. B e rn a s i k, Corr. Protec. 11s, 66 (2005).

[26] A.M. Abd El-R ahman, F.M. E $1-\mathrm{H}$ os s ary, F. Prokert, N.Z. Neg m, E. Richter, W. Moeller, Surf. Coat. Technol. 200, 602 (2005).

[27] E. Cano, L. Martinez, J. S i mancas, F.J. Perez-Trujillo, C. Go mez, J.M. B a stid a s, Surf. Coat. Technol. 200, 5123 (2006).

[28] J. Landoulsi, M.J. Ge net, C. Richard, K. E 1 Ki $\mathrm{r}$ a t, S. P u lv i n, P.G. R o u x h e t, J. of Colloid and Interface Sci. 318, 278 (2008).

[29] A. Ste pu ch-Galik, B. Sty pu ła, Corr. Protec. 7, 196 (2003).

[30] R. B a s ner, R. Foest, M. S ch midt, F. S ige ne ger, P. Ku r u n c zi, K. B e c k e r, H. D e u t s c h, Int. J. Mass Spectrom. Ion Proc. 153, 65 (1996).

[31] P. L e j c e k, Prog. Surf. Sci. 35, 209 (1991).

[32] H. de Rug y, H. Vi e f h a u s, Surf. Sci. 173, 418 (1986).

[33] M. Militzer, Yu.N. Ivashchenko, A.V. Kraj n ikov, P. Le j c e k, J. W i et ing, Prog. Surf. Sci. 35, 205 (1991).

[34] R.D. Wille nbruch, C.R. Clay to n, M. Overs 1 u i z e n, D. K i m, Y. L u, Corros. Sci. 31, 179 (1990).

[35] S.D. Chyou, H.C. Shih, Mater. Sci. Eng. A148, 241 (1991).

[36] A. Li p p it z, Th. H u e b e r t, Surf. Coat. Technol. 200, 250 (2005).

[37] B.P. S w a i n, Surf. Coat. Technol. 201, 1589 (2006).

[38] I. B e r t o t i, Surf. Coat. Technol. 151, 194 (2002).

[39] A.D. Ro m a s chin, L.N. B u i, M. Th o m p s o n, N.B. M c K e o w n, P.G. K a $1 \mathrm{~m}$ a n, Analyst 118, 463 (1993).

[40] J.P. D e vill e, O. B e n k h e r o u ro u, Appl. Phys. A46, 87 (1988).

[41] A. Toth, I. B e rtoti, M. Mohai, M. Reves z, Acta Chim. Hung. - Models in Chem. 130, 837 (1993).

[42] J.A. Tay lor, G.M. L a n c a s te r, J.W. R a b a l a i s, J. Electron Spectrosc. Relat. Phenom. 13, 435 (1978).

[43] L. J i a n g, A.G. Fit z g e r a ld, M.J. R o s e, R. Ch e u n g, B. Rong, E. van der D r if t, Appl. Surf. Sci. 193, 144 (2002).

[44] C. Li, X. Yang, B. Yang, Y. Yan, Y. Qi a n, Mater. Chem. and Phys. 103, 427 (2007).

[45] V. Murphy, S.A.M. Tofail, H. Hughes, P. M c L o u g h 1 i n, Chem. Eng. J. 148, 425 (2009).

[46] M. Tabbal, P. Merel, S. Mois a, M. Chaker, E. G a t, A. Ricard, M. Mois an, S. Gujrathi, Surf. Coat. Technol. 98, 1092 (1998).

[47] T.L. B a r r, J. of Phys. Chem. 82, 1801 (1978).

[48] K. S h i b a g a ki, S. M o to ji m a, Carbon 38, 2087 (2000).

[49] R.F.A. J a r g e 1 i u s - P e t t e r s s o n, Corros. Sci. 41, 1639 (1999).

[50] C.O.A. O 11 s o n, D. L a n d o 1 t, Electrochim. Acta 48, 1093 (2003).

[51] A.A. Herm a s, K. O g u r a, Electrochim. Acta 40, 1601 (1996).

[52] B. Stypuła, D. Kasprzyk, M. Hajos, Archiv. Of Metallurg \& Matter. 54, 305 (2009). 